\title{
A Non-Chromatographic Radioimmunoassay for Plasma Dexamethasone
}

\author{
YING-SHIH LEE AND NAKAAKI OHSAWA \\ The Third Department of Internal Medicine, \\ University of Tokyo Faculty of Medicine, Hongo, 113
}

\section{Synopsis}

\begin{abstract}
A non-chromatographic radioimmunoassay for plasma dexamethasone is presented. Corticosteroid binding protein (CGB) was used to bind endogenous steroids, and free dexamethasone was adsorbed with Florisil. The purified sample was assayed by using an antiserum to dexamethasone-21-BSA. The plasma blank was less than $10 \mathrm{pg}$. When $0.1 \mathrm{~m} l$ of plasma containing $20 \mathrm{ng}$ of cortisol was measured, the blank could not be differentiated from charcoal treated plasma. ${ }^{3} \mathrm{H}$-dexamethasone recovery from purification procedures was $33.2 \pm 4.4 \%$. Accuracy and precision were satisfactory. Plasma dexamethasone concentrations in patients receiving dexamethasone administration are also reported.
\end{abstract}

In radioimmunoassay of plasma dexamethasone, cortisol is a major interfering steroid. In the method reported by Meikle et al. (1973), paper chromatography was utilized to eliminate cortisol interference.

Recently, plasma binding proteins have been used for sample purification in radioimmunoassay (Ismail et al., 1972; Martin and Nugent, 1973). On the base that CBG binds endogenous corticosteroids, including cortisol, and a negligible amount of dexamethasone (Morris et al., 1973), an assay using CBG to purify dexamethasone was developed.

\section{Materials and Methods}

\section{Materials \\ Ethyl acetate, n-hexane and methanol (special grade, Wako Pure Chemical Industries) were used without further purification. Florisil (60-100 mesh, Floridin Co.) was washed, and activated at $150^{\circ} \mathrm{C}$ for 3 hours. $1,2-{ }^{3} \mathrm{H}$-dexamethasone $(29 \mathrm{Ci} / \mathrm{mMole}$, The Radiochemical Centre) was purified by thin layer chromatography in the system of chloroform: ethanol}

Received for publication August 15, 1974.
(9: 1). Dexamethasone was obtained from Sionogi and Co. Other materials used were Bovine serum albumin (Wako Pure Chemical Industries), Pepsin-treated human immune serum globulin (Gamma-Venin, Hoechst Japan Co.), Complete Freund adjuvant (Difco Laboratories), 1-2- ${ }^{3} \mathrm{H}$-cortisol, 1-2- ${ }^{3} \mathrm{H}$-corticosterone, 1-2- ${ }^{3} \mathrm{H}$-deoxycortisol, 1-2- ${ }^{3} \mathrm{H}$-deoxycorticosterone, 1$2-{ }^{3} \mathrm{H}$-progesterone and $1-2-{ }^{3} \mathrm{H}$-testosterone (New England Nuclear).

\section{Antiserum}

Dexamethasone-21-BSA was prepared by follow ing the method of Erlanger et al.(1957). Two mg of the conjugate in $0.8 \mathrm{~m} l$ saline was mixed with $0.8 \mathrm{ml}$ complete Freund adjuvant, and injected to a rabbit. The injection was given fortnightly for the first 3 months, and monthly thereafter. The antiserum obtained in the $3 \mathrm{rd}$ month was useful at $1: 10,000$ dilution.

\section{Plasma extraction and purification}

One tenth $\mathrm{m} l$ of plasma sample and $1 \mathrm{ml}$ of borate buffer $(0.05 \mathrm{M}, \mathrm{pH} 7.8)$ were pipetted into the tube containing 2,000 $\mathrm{cpm}$ of ${ }^{3} \mathrm{H}$-dexamethasone. The solution was incubated in ice water bath for $30 \mathrm{~min}$. Eighty $\mathrm{mg}$ of Florisil was added to the sample, and shaken for $1 \mathrm{~min}$. After the supernatant was removed, the Florisil was washed twice with $1 \mathrm{ml}$ of borate buffer. The Florisil was extracted in a mixture of $1 \mathrm{ml}$ of water with $2 \mathrm{ml}$ of ethyl acetate: n-hexane (7:3). The ethyl acetate: $n$-hexane layer was aspirated to another tube, and 
the water layer was discarded. One $\mathrm{m} l$ of water was pipetted to the Florisil, and it was extracted with $2 \mathrm{ml}$ of ethyl acetate. The ethyl acetate was aspirated to the tube containing ethyl acetate: n-hexane, and evaporated. Then, after adding $0.1 \mathrm{~m} l$ of characoal treated plasma to the residue, the procedures of Florisil adsorption and extraction were repeated. The residue was redissolved in $1 \mathrm{~m} l$ of methanol. Two tenth $\mathrm{m} l$ aliquot was counted for recovery.

\section{Radioimmunoassay}

For radioimmunoassay, 0.1 to $0.2 \mathrm{ml}$ of plasma extracts dissolved in methanol and standards containing $10,20,30,50,100$ and $200 \mathrm{pg}$ of dexamethasone were pipetted into assay tubes, and dried. Then, $0.25 \mathrm{ml}$ of appropriately diluted antiserum with $3,000 \mathrm{cpm}{ }^{3} \mathrm{H}$ dexamethasone in borate buffer containing $0.1 \%$ pepsin treated human immune serum globulin and $0.06 \% \mathrm{BSA}$ was added to the sample. After incubation overnight at $4^{\circ} \mathrm{C}, 0.25 \mathrm{ml}$ of saturated ammonium sulfate was added, the mixture was stirred, and centrifuged at $3,000 \mathrm{rpm}$ for $15 \mathrm{~min}$. The radioactivity in $0.25 \mathrm{ml}$ of the supernatant was counted in the Aloka model LSC502 liquid scintillation counter.

\section{Plasma cortisol}

Plasma cortisol was estimated by the radioassay method of Murphy (1967).

\section{Results}

\section{Standard curve}

A typical standard curve in the range of 0 to $200 \mathrm{pg}$ dexamethasone is shown in Figure 1.

\section{Blank}

Blank of charcoal treated plasma was less than $10 \mathrm{pg}$. When plasma containing less than $20 \mathrm{ng}$ of cortisol was measured, the blank could not be differentiated from steroid-free plasma (Table 1).

\section{Recovery, specificity and sensitivity}

The rate of recovery of dexamethasone from the purification procedures was $33.2 \pm$ $4.4 \%$. (Table 2 ).

Cross reactions of various endogenous steroids were determined at the $1 \mathrm{ng}$ level for dexamethasone antiserum. The interference by endogenous steroids could be reduced after

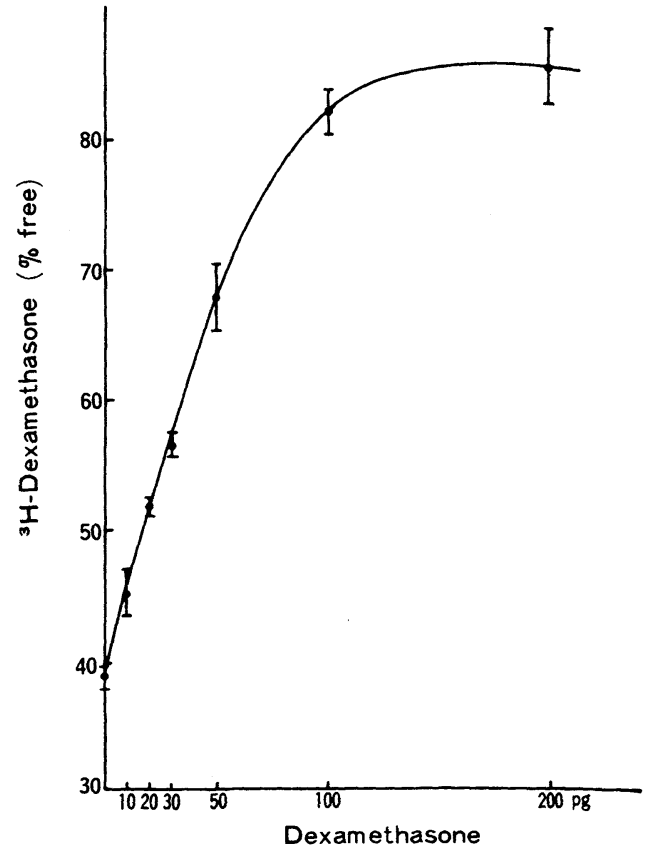

Fig. 1. Standard curve for dexamethasone. (mean $\pm \mathrm{SD}, \mathrm{n}=5$ )

Table 1. Cortisol interference

\begin{tabular}{ccc}
\hline $\begin{array}{c}\text { Cortisol added } \\
\text { (ng) }\end{array}$ & $\begin{array}{c}\text { Dexamethasone } \\
\text { added }(\mathrm{pg})\end{array}$ & $\begin{array}{c}\text { Dexamethasone } \\
\text { measured }(\mathrm{pg})\end{array}$ \\
\hline 0 & 0 & undetectable \\
10 & 0 & undetectable \\
20 & 0 & undetectable \\
30 & 0 & $125^{*}$ \\
40 & 0 & $375^{*}$ \\
50 & 0 & $440^{*}$ \\
\hline 0 & 300 & 289 \\
10 & 300 & 306 \\
20 & 300 & 340 \\
30 & 300 & 481 \\
\hline
\end{tabular}

Steroids were added in $0.1 \mathrm{~m} l$ of charcoal treated plasma.

*Values were expressed as dexamethasone equivalent.

CBG purification. When $300 \mathrm{pg}$ of dexamethasone was added to plasma containing 0 , 10,20 and $30 \mathrm{ng}$ of cortisol, the recovery was $289,306,340$ and $481 \mathrm{pg}$, respectively. (Table 1). 
Table 2. Steroids recovery from purification, antibody cross reactivity and overall specificity of the assay

\begin{tabular}{lccc}
\hline & $\begin{array}{c}\text { Recovery } \\
(\%)\end{array}$ & $\begin{array}{c}\text { Cross } \\
\text { reactivity* } \\
(\%)\end{array}$ & $\begin{array}{c}\text { Overall } \\
\text { specificity } \\
(\%)\end{array}$ \\
\hline Dexamethasone & 33.2 & 100 & 100 \\
Cortisol & 1.7 & 3.5 & 0.18 \\
Corticosterone & 1.2 & 3.9 & 0.14 \\
Deoxycortisol & 1.8 & 3.6 & 0.20 \\
Deoxycortico- & 2.0 & 9.1 & 0.55 \\
$\quad$ sterone & & & \\
Progesterone & 1.7 & 3.7 & 0.19 \\
Testosterone & 5.5 & 10.9 & 1.8 \\
\hline Betamethasone & & 7.9 & \\
Prednisolone & & 6.7 & \\
\hline
\end{tabular}

* Values were based on the competition of $1 \mathrm{ng}$ of each steroid with ${ }^{3} \mathrm{H}$-dexamethasone for binding sites on the antibody.

$\uparrow$ For example: cortisol $=1.7 / 33.2 \times 3.5$

The minimal detectable amount of dexamethasone on the standard curve was $8 \mathrm{pg}$.

\section{Precision}

In order to determine intra-assay precision, 200 and $500 \mathrm{pg}$ of dexamethasone were added to $0.1 \mathrm{~m} l$ of steroid-free plasma. The coefficient of variation was $13.8 \%$ and $9 \%$, respectively $(\mathrm{N}=6)$. When these samples were analyzed on different days, the coefficient of variation were $12.8 \%$ and $14.6 \%$, respectively.
Table 3. Plasma dexamethasone

\begin{tabular}{rccc}
\hline $\begin{array}{c}\text { Plasma } \\
\text { cortisol } \\
(\mu \mathrm{g} / \mathrm{d} l)\end{array}$ & $\begin{array}{c}\text { Plasma } \\
\text { dexame- } \\
\text { thasone } \\
(\mathrm{ng} / \mathrm{d} l)\end{array}$ & $\begin{array}{c}\text { Dexame- } \\
\text { thasone } \\
\text { administered } \\
(\mathrm{mg})\end{array}$ & $\begin{array}{c}\text { Time after } \\
\text { administ- } \\
\text { ration } \\
(\mathrm{hrs})\end{array}$ \\
\hline 2.7 & undetectable & 0 & - \\
7.5 & undetectable & 0 & - \\
15.3 & undetectable & 0 & - \\
20.8 & undetectable & 0 & - \\
\hline$* 1.9$ & 301 & 0.5 & 5 \\
1.7 & 238 & 1 & 7 \\
21.5 & undetectable & 1 & 10 \\
7.6 & undetectable & 1 & 10 \\
7.8 & 623 & 8 & 10 \\
9.3 & 768 & 16 & 10 \\
\hline
\end{tabular}

* Plasmas were from patients receiving oral dexamethasone treatment or suppression test.

\section{Accuracy}

Accuracy was examined by adding 200, 500, $1000 \mathrm{pg}$ of dexamethasone to $0.1 \mathrm{ml}$ of charcoal treated plasma, and analyzing them. The recovery was $111.7 \pm 15.5,97.4 \pm 8.8$ and $99.3 \pm 10.4 \%$, respectively.

\section{Plasma concentration}

Plasma dexamethasone levels after receiving oral dexamethasone administration are shown in Table 3 and Figure 2. When plasma dexamethasone and cortisol were estimated after $1 \mathrm{mg}$ oral dose of dexame-

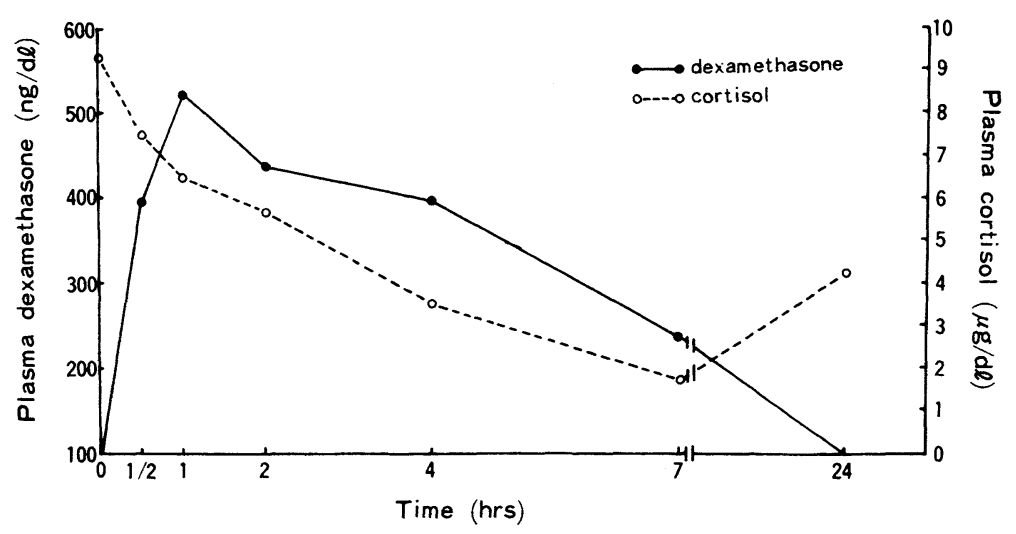

Fig. 2. Plasma dexamethasone and cortisol levels after a single dose of dexamethasone (1 mg). 
thasone, dexamethasone levels reached a peak of $521 \mathrm{ng} / \mathrm{d} l$ in $1 \mathrm{hr}$, and decreased to 238 $\mathrm{ng} / \mathrm{d} l$ in $7 \mathrm{hr}$. Plasma cortisol level decreased from $9.3 \mu \mathrm{g} / \mathrm{d} l$ to $1.7 \mu \mathrm{g} / \mathrm{d} l$ in $7 \mathrm{hrs}$, and returned to $4.2 \mu \mathrm{g} / \mathrm{d} l$ in $24 \mathrm{hrs}$ while plasma dexamethasone was undetectable.

\section{Discussion}

A non-chromatographic radioimmunoassay for plasma dexamethasone is reported. The endogenous corticosteroids bound to $\mathrm{CBG}$ were separated from free dexamethasone which was adsorbed with Florisil. Although the recovery of ${ }^{3} \mathrm{H}$-dexamethasone in present method was lower than those in radioimmunoassays containing chromatographic purification, accuracy and precision were satisfactory. After CBG purification, recovery of most of the endogenous steroids were about $2 \%$ or less, with the exception of testosterone (Table 2). In plasma obtained from normal person, endogenous steroids in this concentration will not significantly interfere with the assay. However, in patients with hypercorticism or pregnant women, the high level of cortisol and progesterone will give rise to significant interference. The plasma values determined after oral dexamethasone administration approximate those which have been reported (Meikle et al., 1973) and the values were depended on subject, dosage and time of sampling. The method presented here is less time consuming by eliminating chro. matography and is expected to be a simple method suitable for routine use in estimating plasma dexamethasone in patients receiving dexamethasone administration, almost all of them plasma cortisol is suppressed.

\section{Acknowledgement}

We wish to express appreciation to Prof. Kinori Kosaka, the Director of the Third Department of Internal Medicine, University of Tokyo Faculty of Medicine, for his advice and encouragements throughout these studies. A valuable help and cooperation of Dr. Satoshi Yamamoto, Central Institute for Experimental Animals, Kawasaki, is also appreciated.

\section{References}

Erlanger, B. F., F. Borek, S. Beiser and S. Lieberman (1957). J. Biol. Chem. 228, 713. Ismail, A. A. A., G. D. Niswender and A. R. Jr. Midgley (1972). J. Clin. Endocr. 34, 177.

Martin, B. T., and C. A. Nugent (1973). Steroids 21, 169.

Meikle, A. W., L. G. Lagerquist and F. H. Tyler (1973). Steroids 22, 193.

Morris, H. G., G. Deroche and C. M. Caro (1973). Ibid. 22, 445.

Murphy, B. E. P. (1967). J. Clin. Endocr. 27, 973. 